\title{
Comparative Study on Decomposition of Leaf Litter between a Warm-temperate Evergreen Oak Forest and a Tropical Rain Forest
}

\author{
ChaIRUL Department of Biology, Faculty of Science, Andalas University, Padang, West \\ Sumatra, Indonesia \\ Tsuyoshi YONEDA Department of Environmntal Sciences and Technology, Faculty of Agriculture, \\ Kagoshima University, 1-21-24 Kourimoto, Kagoshima 890-0065, Japan
}

\begin{abstract}
Decomposition processes of leaf litter were observed during one year with same kinds of substrates at a warm-temperate evergreen oak forest in Japan and a tropical rain forest in Sumatra simultaneously. A warm-temperate forest showed high rates of carbon-weight loss in summer. A tropical rain forest had high rates at the initial stages in particular and apparently low rates during the severe dry weather in early 1997. When time trends of carbon-weight loss could be approximated by a single exponential curve for each leaf litter, the average values of decomposition factor of five Japanese fagaceous leaf litter were $0.70 \pm 0.13 \mathrm{y}^{-1}$ at a warm-temperate forest and $1.62 \pm 0.24 \mathrm{y}^{-1}$ at a tropical rain forest, respectively. The $C / N$ ratios of litter gradually decreased with the progress of decomposition at the initial stages, then tended to be constant at about $C / N=20$ at the last stages irrespective of kinds of leaf litter and study sites. Basing on these results we discussed characteristics of decomposition at these two forest ecosystems.
\end{abstract}

Key words: carbon cycling / $C / N$ ratio / decay rates / leaf litter / litter-bag / $\mathrm{Q}_{10}$ value / seasonal changes / dry-weather

Decomposition processes of forest litter are influenced by various factors such as physical and chemical properties of substrates, temperature, humidity and kinds of decomposers (Kuhnelt, 1961; Whitkamp, 1966; Swift et al., 197; Yoneda, 1986). It is one of important features of a forest ecosystem. How do climatic factors affect the processes by themselves? How do seasonal changes of climate characterize the processes in the warm-temperate region against non-seasonal climate in the humid tropics? This study aims to compare decomposition processes between a warm-temperate evergreen oak forest and a tropical rain forest with special reference to annual decay rates (Ogawa et al., 1961: Olson, 1963: Yoda \& Kira, 1969), seasonality (Kirita \& Hozumi, 1969: Swift et al., 1979) and changes of $C / N$ ratios of substrates (Dowding, 1976).

We observed the processes of leaf litter on the forest floor by the litter-bag method. Same kinds of leaf litter were used for this experiment at both sites in order to remove effects of substrates. Changes of carbon weights and $C / N$ ratios of these litter samples were observed at an interval of three months during one year. We assessed influences of climatic factors on decay rates, and discussed features of 

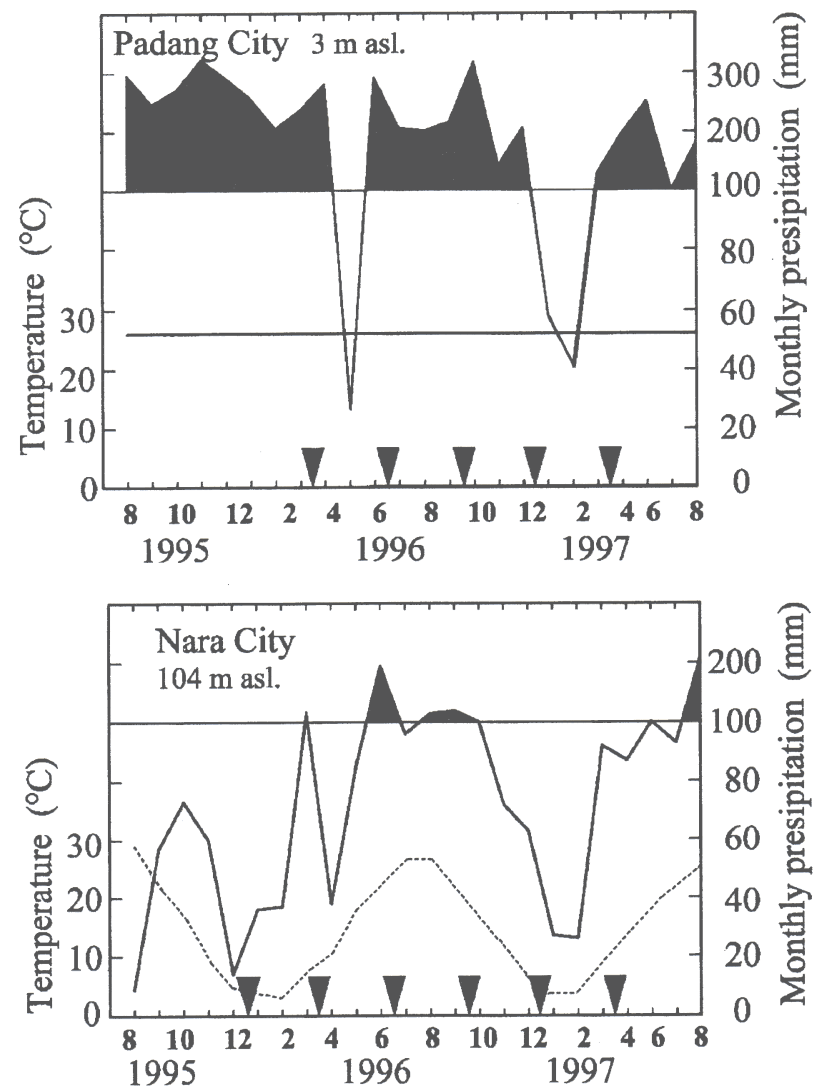

Fig. 1. Modified Walter's Climatic Diagrams at the nearest meteorological stations during the observation period. Closed triangles in diagrams show dates of the initial setting and each collection of litter-bags.

decomposition of a warm-temperate evergreen oak forest in central Japan and an equatorial rain forest in West Sumatra comparatively.

\section{MATERIALS AND METHODS}

Study Sites This study was simultaneously conducted at a warm-temperate evergreen oak forest in Nara, Japan and a tropical rain forest in West Sumatra, Indonesia. The former forest was located in a preserved forest area (Koshimizu et al., 1971) of Mt. Miksa (294 m a.s.l., 00² 41' N, $\left.135^{\circ} 51^{\prime} \mathrm{E}\right)$, Nara City. A study site was covered by a mature evergreen oak forest dominated by some Querucus (Cyclobalanopsis) spp. and Castanopsis cuspidata. Neolitsea aciculata was abundant in a sub-tree layer particularly, and Podocarpus nagi being one of dominant species in Mt. Mikasa (Nanami et al., 1999) was few at this site. The site was nearly flat on a ridge at the foot of a mountain topographically and was $220 \mathrm{~m}$ a.s.1.. Average temperature and annual rainfall of this site in 1996 were estimated at $13.0{ }^{\circ} \mathrm{C}$ and $1221 \mathrm{~mm}$ from the nearest Nara Meteorological Station, respectively (Fig. 1). We 
Table 1. Initial chemical conditions of leaf litter for this litter-bag experiment. Symbols of JFS and SFS show Japanese and Sumatran fagaceous species, respectively.

\begin{tabular}{llcccc}
\hline Groups & \multicolumn{1}{c}{ Species } & $\begin{array}{c}\text { Number of } \\
\text { samples }\end{array}$ & Carbon $(\%)$ & Nitrogen $(\%)$ & $C / N$ ratio \\
\hline JFS & Castanopsis cuspidata & 2 & $49 \pm 0.4$ & $1.6 \pm 0.1$ & $31 \pm 1.6$ \\
JFS & Quercus gilva & 2 & $48 \pm 0.8$ & $1.7 \pm 0.2$ & $29 \pm 3.4$ \\
JFS & Q. glauca & 2 & $48 \pm 0.8$ & $1.7 \pm 0.2$ & $28 \pm 2.0$ \\
JFS & Q. salicina & 2 & $48 \pm 0.2$ & $1.5 \pm 0.0$ & $32 \pm 0.0$ \\
JFS & Q. sessilifolia & 2 & $49 \pm 0.7$ & $1.5 \pm 0.0$ & $32 \pm 0.2$ \\
SFS & C. costata & 1 & 49 & 1.2 & 42 \\
SFS & Lithocarpus histrix & 1 & 48 & 1.3 & 36 \\
SFS & L. meijerii & 1 & 47 & 1.5 & 32 \\
SFS & Q. argentata & 1 & 47 & 1.5 & 31 \\
SFS & Q. oidocorpa & 1 & 50 & 1.3 & 40 \\
\hline
\end{tabular}

abbreviated this study site as MIKASA after Mt. Mikasa.

Study in a tropical rain forest was carried out at a mature forest stand in the biological school forest $\left(00^{\circ} 55^{\prime} \mathrm{S}, 100^{\circ} 28^{\prime} \mathrm{E}\right)$ of Andalas University, being $17 \mathrm{~km}$ east of Padang City, West Sumatra, Indonesia. A site was located on a gentle slope, $370 \mathrm{~m}$ a.s.1., of a small hill. Fagaceae showed high dominance at a canopy layer, being composed of Lithocarpus spp., Querucus spp. and Castanopsis spp. Abundance of L. meijerii Soepadomo and Q. argentata Kortalsii was high in particular. This region was highly humid throughout the year, having average annual rainfall $4000 \mathrm{~mm}$ without any month under $200 \mathrm{~mm}$ average monthly rainfall during the last 69 years. Severe dry weather, however, attacked this area in May 1996 and the initial two months in 1997 during this study period (Yoneda et al., 2000). Annual mean temperature was estimated at $23.9^{\circ} \mathrm{C}$ from the nearest Padang (Tabing Airport) Meteorological Station (3 m a.s.l.). We abbreviated this study site as HPPB after Indonesian name of the biological school forest.

Materials We used five kinds of Japanese evergreen fagaceous leaves (JFS) as the major materials of this study. They were Castanopsis cuspidata (Thunberg) Schottky, Quercus gilva Blume, Q. glauca Thunberg, Q. salicina Blume and Q. sessilifolia Blume. Leaves of these species were collected from living trees at MIKASA in early December 1995 and air-dried leaves were used for this experiment of litter-bags. We also used five kinds of Sumatran fagaceous leaves (SFS) as reference materials. They were composed of $C$. costata A.DC., Lithocarpus hystrix (Korth.) Rehd., L. meijerii Soepadmo, $Q$. argentata Korthalsii and $Q$. oidocarpa Korthalsii. Newly fallen leaves of these species were collected in HPPB. Initial carbon and nitrogen concentrations of these JFS and SFS leaves were shown in Table 1.

Methods Ten grams of air-dried leaves of each species were enclosed in a litter-bag with $1 \mathrm{~mm}$ mesh and $15 \mathrm{~cm} \times 15 \mathrm{~cm}$ area. Nineteen litter-bags of each JFS were set on the forest floor at MIKASA in middle December 1995, and twenty litter-bags of each JFS and SFS were set at HPPB in late March 1996. Litter-bags of each species were collected at an interval of three months at both study sites. Collection was repeated five times during 1.24 years at MIKASA ( 4 times $\times 4$ bags +1 time $\times 3$ bags=19 bags) and four times during 1.00 year at HPPB ( 4 times $\times 5$ bags=20 bags). Collected samples were cleaned by removing attached soils, and their oven-dry weights were measured. All samples were pulverized, and their carbon and nitrogen concentrations were analyzed by C-H-N corder (Yanako MT-3) at Osaka Kyoiku University, Japan. 


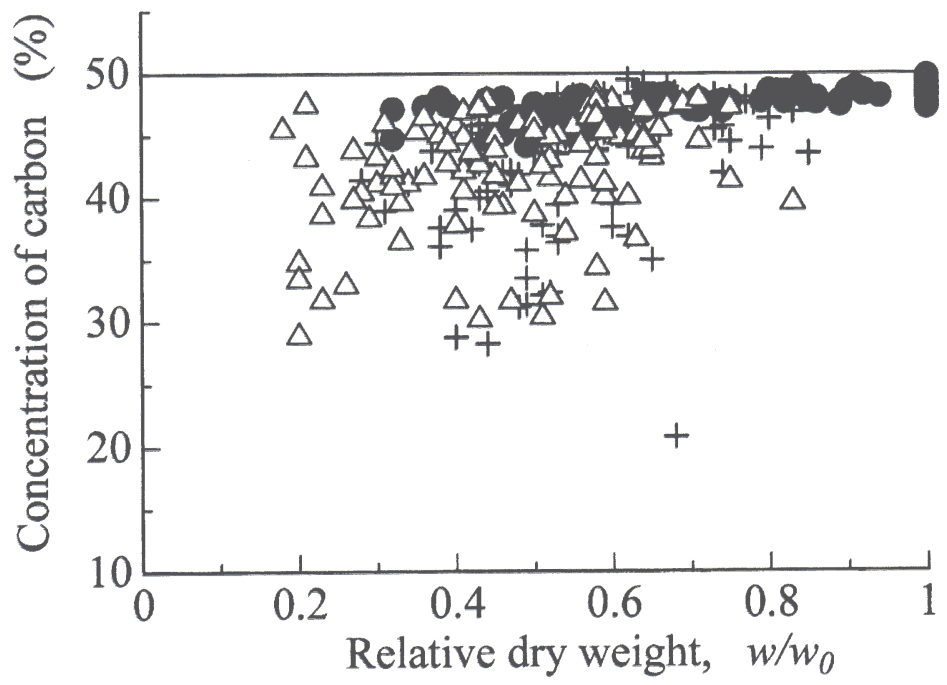

Fig. 2 Relationships between relative weights of dry matter $\left(w / w_{0}\right)$ and carbon concentrations of all collected leaf litter samples. Closed circles, triangles and crosses are Japanese fagaceous samples (JFS) at MIKASA, JFS at HPPB and Sumatran fagaceous samples (SFS) at HPPB, respectively.

\section{RESULTS}

Seasonal changes of decomposition factor $\mu_{\mathrm{c}}$ Carbon concentrations of collected litter samples at HPPB in particular tended to decrease with the decrease of their weights of dry matter irrespective of JFS and SFS (Fig.2). We considered soil contamination to be the main reason of this result, and then assessed the progress of decomposition by losses of their carbon weights.

Relative carbon weight to the initial value of each sample at MIKASA approximately decreased exponentially with time, $t$, and the relationships of five JFS could be regressed by the following equation with high coefficient of correlation (Table $2: \mathrm{r}^{2}>0.92$ ).

$$
C(t)=C_{0} \exp \left(-\mu_{\mathrm{C}} t\right) t
$$

where $C_{0}, C(t)$ and $\mu_{\mathrm{c}}$ are carbon weights of a sample at $t=0$ and a given time, and a decomposition factor being defined as $\mu=-\frac{1}{C} \frac{d C}{d t}$, respectively. The JFS and SFS at HPPB also showed the similar $C(t) / C_{0}$ - $t$ relations, but coefficients of correlation being $\mathrm{r}^{2}=0.15-0.85$ for JFS and $\mathrm{r}^{2}=0.13-0.75$ for SFS were lower than those at MIKASA. $Q$. gilva and $Q$. oidocarpa at HPPB in particular showed low correlation because of their large depression of decay rates during the last three months under severe dry weather (cf. Table 3 ).

We examined seasonal changes of $\mu_{\mathrm{c}}$ values in both study sites. When Eq.(1) could be applied to weight decrease during each three months of the interval, $\mu_{c}$ values during the period could be calculated by

$$
\mu_{\mathrm{c}}=-\ln \left\{\left[\mathrm{C}(i+\mathrm{r}) / C_{0}(i+\mathrm{r})\right] /\left[\mathrm{C}(i) / C_{0}(i)\right]\right\} / 3 \text { months }
$$


Table 2. The final $C / C_{0}$ ratios and decomposition factors $\left(\mu_{c}\right)$ of each leaf litter during the whole observation periods being 1.24 years at MIKASA and 1.00 year at HPPB. The symbols of $n$ and $r$ were numbers of samples and coefficient of correlation, respectively.

\begin{tabular}{|c|c|c|c|c|c|c|c|c|c|}
\hline \multirow{2}{*}{ Groups } & \multirow{2}{*}{ Species } & \multicolumn{4}{|c|}{ MIKASA } & \multicolumn{4}{|c|}{ HPPB } \\
\hline & & $\mathrm{n}$ & final $C / C_{0}$ & $\mu_{\mathrm{C}}\left(\mathrm{y}^{-1}\right)$ & $\mathrm{r}^{2}$ & $\mathrm{n}$ & final $C / C_{0}$ & $\mu_{c}\left(y^{-1}\right)$ & $\mathrm{r}^{2}$ \\
\hline JFS & C. cuspidatn & 19 & 0.35 & 0.89 & 0.96 & 20 & 0.15 & 1.96 & 0.85 \\
\hline JFS & Q. gilva & 19 & 0.55 & 0.53 & 0.95 & 20 & 0.36 & 1.30 & 0.15 \\
\hline JFS & Q. glauca & 19 & 0.43 & 0.72 & 0.97 & 20 & 0.28 & 1.44 & 0.75 \\
\hline JFS & Q. salicina & 19 & 0.37 & 0.78 & 0.92 & 20 & 0.24 & 1.49 & 0.83 \\
\hline JFS & Q. sessilifolia & 19 & 0.47 & 0.59 & 0.93 & 20 & 0.33 & 1.19 & 0.84 \\
\hline SFS & C. costata & - & - & - & - & 20 & 0.39 & 1.06 & 0.75 \\
\hline SFS & L. histrix & - & - & - & - & 20 & 0.33 & 1.24 & 0.69 \\
\hline SFS & L. meijerii cf. & - & - & - & - & 20 & 0.31 & 1.34 & 0.68 \\
\hline SFS & Q. argentata & - & - & - & - & 20 & 0.51 & 0.69 & 0.65 \\
\hline SFS & Q. oidocorpa & - & - & - & - & 20 & 0.33 & 1.41 & 0.13 \\
\hline
\end{tabular}

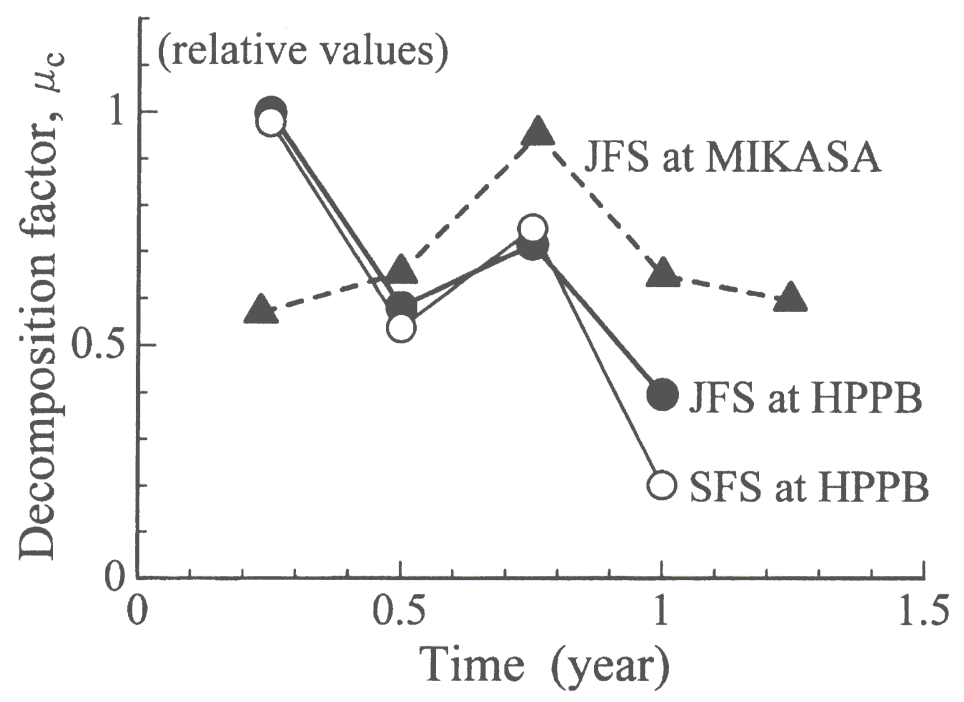

Fig. 3 Time trends of average decomposition factors $\left(\mu_{c}\right)$, being the coefficient of weight decrease of carbon, at MIKASA (broken line) and HPPB (solid lines).

where $C(i) / C_{0}(i)$ and $C(i+\mathrm{r}) / C_{0}(i+\mathrm{r})$ are ratios of $C(t) / C_{0}$ at the $i$ th and $(i+1)$ th collection, respectively. We assessed seasonal changes of $\mu_{\mathrm{c}}$ of each species by its relative value to the maximum value.

Figure 3 shows their seasonal changes for five species at both sites. MIKASA (JFS) had the highest $\mu_{\mathrm{c}}$ value at the third period of collection between middle June and middle September 1996. The value was significantly higher than values at the two former periods $(\mathrm{P}<0.01)$ and the following two periods $(\mathrm{P}<0.05)$. Samples of JFS and SFS at HPPB showed similar time trends of their $\mu_{\mathrm{c}}$ with each other. They had the highest values during the first three months between late March and late June 1996, though the period suffered severe dry weather in May whose monthly rainfall was $27 \mathrm{~mm}$. Then $\mu_{\mathrm{c}}$ values largely decreased during the last three months under dry weather in January and February 
Table 3. Average decomposition factors $\left(\mu_{\mathrm{c}}, \mu_{\mathrm{cS}}\right)$ of each leaf litter during the periods being the initial 1.00 year at MIKASA and the initial 0.75 year before the dry weather 1997 at HPPB. The symbol of Q10 is the temperature coefficient. *:an average value except $\mathrm{Q}$. argentata.

\begin{tabular}{lcccccccc}
\hline Species & $\mathrm{n}$ & $\begin{array}{c}\text { MIKASA } \\
\mu_{\mathrm{cj}}\left(\mathrm{y}^{-1}\right)\end{array}$ & $\mathrm{r}^{2}$ & $\mathrm{n}$ & $\begin{array}{c}\mathrm{HPPB} \\
\mu_{\mathrm{cS}}\left(\mathrm{y}^{-1}\right)\end{array}$ & $\mathrm{r}^{2}$ & $\mu_{\mathrm{cs}} / \mu_{\mathrm{cj}}$ & Q10 \\
\hline C.cuspidata & 16 & 0.89 & 0.95 & 15 & 2.04 & 0.76 & 2.29 & 2.13 \\
Q. gilva & 16 & 0.54 & 0.94 & 15 & 1.60 & 0.51 & 2.97 & 2.70 \\
Q. glauca & 16 & 0.73 & 0.97 & 15 & 1.62 & 0.91 & 2.21 & 2.07 \\
Q. salicina & 16 & 0.75 & 0.96 & 15 & 1.55 & 0.69 & 2.07 & 1.94 \\
Q. sessilifolia & 16 & 0.57 & 0.91 & 15 & 1.28 & 0.81 & 2.26 & 2.10 \\
$\quad$ average & - & $0.70 \pm 0.13$ & - & - & $1.62 \pm 0.24$ & - & $2.36 \pm 0.312 .19 \pm 0.26$ \\
C. costata & - & - & - & 15 & 1.21 & 0.84 & & \\
L. histrix & - & - & - & 15 & 1.41 & 0.75 & & \\
L. meijerii & - & - & - & 15 & 1.51 & 0.80 & & \\
Q. argentata & - & - & - & 15 & 0.71 & 0.26 & & \\
Q. oidocorpa & - & - & - & 15 & 1.74 & 0.74 & & \\
\multicolumn{1}{c}{ average } & - & - & - & - & $1.47 \pm 0.19^{*}$ & - & & \\
\hline
\end{tabular}

being $59 \mathrm{~mm}$ and $42 \mathrm{~mm}$ monthly rainfall, respectively (Fig. 1). The $\mu_{\mathrm{c}}$ values of SFS at the last period were significantly lower than those in the former period $(\mathrm{P}<0.01)$.

Comparison of annual mean $\mu_{c}$ values between MIKASA and HPPB We estimated the annual mean $\mu_{\mathrm{c}}$ values at MIKASA from data during the first one year except the last three months because of avoiding the repetition of the same season. In the case of HPPB we estimated the values from data during the first nine months except the last period suffering abnormal dry weather in 1997. Table 3 shows the average value of each species at both sites. When we estimated $\mu$ values on basis of dry matter weight with some contaminant of soils, the $\mu$ values accounted for $95 \%$ of the $\mu_{\mathrm{c}}$ value at MIKASA $\left(r^{2}=0.97\right)$ and $85 \%$ at HPPB $\left(r^{2}=0.88\right)$.

Calculated $\mu_{\mathrm{c}}$ values of five JFS species at MIKASA and HPPB ranged from $0.54 \mathrm{y}^{-1}$ to $0.89 \mathrm{y}^{-1}$ and from $1.28 \mathrm{y}^{-1}$ to $2.04 \mathrm{y}^{-1}$, respectively. These values showed positive correlation between two sites $\left(\mathrm{r}^{2}=0.63\right)$, and $C$. cuspidata had the highest value at both sites. An average value at HPPB was 2.4 times of MIKASA. Five SFS at HPPB had the maximum range from $0.71 \mathrm{y}^{-1}$ to $1.74 \mathrm{y}^{-1}$. The average value of four SFS except $Q$. argentata with distinctly low correlation was not significantly different with that of JFS at HPPB.

Temperature would be the major factor to cause these large differences between MIKASA and $\mathrm{HPPB}$, and we assessed the influences with the temperature coefficient of $\mathrm{Q}_{10}$ (Table 3). The $\mathrm{Q}_{10}$

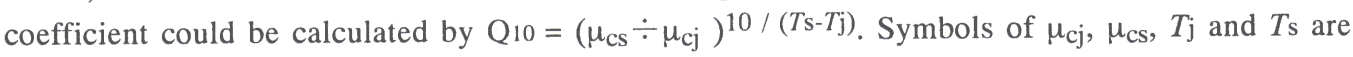
average $\mu_{\mathrm{c}}$ values and annual mean temperature at MIKASA and HPPB, respectively. Average $\mathrm{Q}_{10}$ value for five JFS was $2.19 \pm 0.26$.

Changes of $C / N$ ratio in decomposition process The $C / N$ ratio of each species decreased with the progress of decay at both study sites, and tended to keep a constant value, around 20, at the latter stages irrespective of species and sites (Fig. 4). The initial decrease of $C / N$ ratio was nearly proportional to the decrease of carbon content without losses of nitrogen. The $\mathrm{C} / C_{0}-C / N$ relations of five JFS species were not largely different between MIKASA and HPPB, and one asymptotic curve could approximate their relations. 

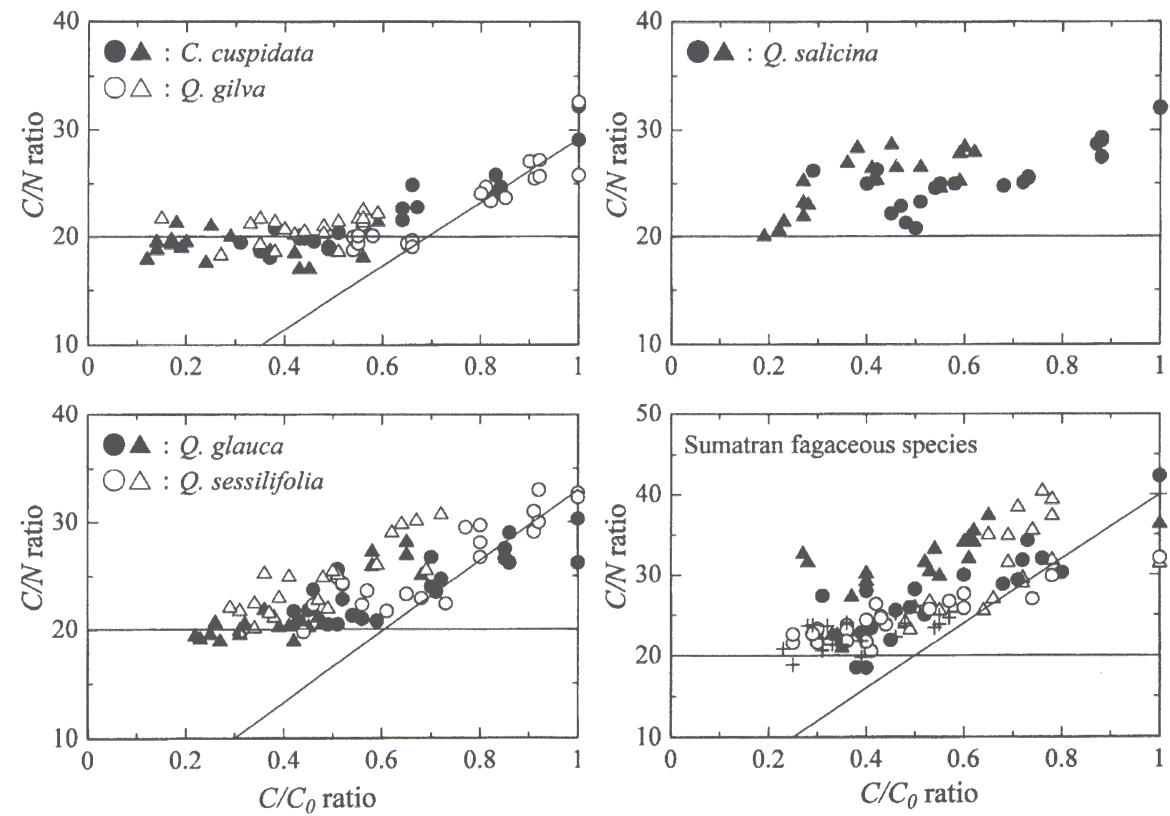

Fig. 4 Relationships between $C / C_{0}$ ratio and $C / N$ ratio of leaf litter. A straight line with a positive gradient shows the expected relations at the case of no losses of nitrogen. Circles and triangles in three diagrams except the lower right show leaf litter of JFS at MIKASA and HPPB, respectively. Five symbols at a lower right diagram show five kinds of leaf litter of native species (SFS) at HPPB.

\section{DISCUSSIONS}

\section{Comparison of weight loss processes of leaf litter between two forest ecosystems}

The $C / N$ ratios of leaf litter tended to be constant at the latter stages of decomposition irrespective of species and sites. The asymptotic value was 20 . Nitrogen of litter is usually used for construction of microbial tissues at the initial stages, and is immobilized until the critical point (Dowding, 1976) which nitrogen production by decomposers exceeds their assimilation. The asymptotic value would correspond to this critical point. Gotz et al. (1973) showed the critical point of birch leaves with the initial $C / N=62$ at the Hubbard Brook Experimental Forest at New Hampshire to be $C / N=30$. Staaf \& Berg (1982) estimated the value of Scots pine needle with the initial $C / N=134$ in Central Sweden to be $C / N=60$. Dowding (1976) suggested the critical point to be site specific. Critical points at our two study sites, however, were nearly equivalent. This suggests that nitrogen metabolism on decomposition processes of these leaf litter was not largely different between a temperate oak forest in Japan and a tropical rain forest in Sumatra. Gradual decrease of $C / N$ ratios at the initial stages would show the incorporation by decomposers. When termites played major roles as decomposers, dry matter loss progressed without apparent decrease of $C / N$ ratio (Yoneda, 2000). Then decay processes of this study would be promoted by fungi association as major decomposer instead of termites, though we could observed some termite mounds at HPPB. 
Physical and chemical properties of decomposing substrates largely affect decay rates as much as environmental factors such as temperature and humidity, and they continuously changes in progress of decay (Witkamp, 1966: Yoneda, 1975: Swift et al., 1979). Therefore starting time of decomposition is an important parameter at sites having clear seasonal changes in climate because of interaction of internal factors and environmental factors (Swift et al., 1979). Exponential decrease of carbon weights at MIKASA would result from the start in winter season with low microbial activities. When we commence this experiment in May having the maximum leaf-fall rates of these evergreen fagaceous species in a year (Nishioka \& Kirita, 1978), different patterns would occur because of larger weight loss at the initial stages (Kirita \& Hozumi, 1969). Exponential patterns at MIKASA, therefore, would be analogous to that of deciduous trees having defoliation in autumn.

High decay rates during the initial three months at HPPB would result from rapid losses of soluble and easily decomposable substances under conditions of high temperature and high rainfall. Large depression of $\mu_{\mathrm{c}}$ values at the last three months could be observed, and $\mu_{\mathrm{c}}$ values of four kinds of leaf litter out of ten species were zero during the period. This phenomenon would be apparently caused by severe dry weather in early 1997. During the period vigorous trees with high growth rates before the event largely decreased their stem growth, and high rates of leaf-fall were observed in this forest at HPPB (Yoneda et al., 2000). We could expect that this forest ecosystem largely decreased flow rates of production and decomposition processes both during the period. Trees also deceased their stem growth in May 1996 suffering short-termed dry weather (Yoneda et al., 2000), then the initial $\mu_{\mathrm{c}}$ values during the period would be affected to some extent by this dry weather.

Annual mean $\mu_{\mathrm{c}}$ value of five JFS at MIKASA was estimated at $0.70 \pm 0.13 \mathrm{y}^{-1}$. This value was within the range $\left(0.41-0.81 \mathrm{y}^{-1}\right)$ of $\mu_{\mathrm{c}}$ values of fine litter in $\mathrm{A}_{0}$-layer, being calculated as a ratio of annual litter-fall rate to annual soil respiration rate from the layer, at a similar vegetational forest 300$350 \mathrm{~m}$ a.s.1. in neighboring Mt. Kasuga (Nakane, 1975). Basing on the same model Kira (1978) estimated $\mu_{\mathrm{c}}$ values of fine litter in $\mathrm{A}_{0}$-layer to be $0.80 \mathrm{y}^{-1}$ at an evergreen oak forest, being $480 \mathrm{~m}$ a.s.l. and $13.8^{\circ} \mathrm{C}$ average annual mean temperature at Minamata, Southern Japan. Differences of annual temperature considered, estimated $\mu_{\mathrm{c}}$ values of this study at MIKASA would be reasonable.

Average $\mu_{\mathrm{c}}$ values at HPPB $370 \mathrm{~m}$ a.s.l. were $1.62 \pm 0.24 \mathrm{y}^{-1}$ of JFS and $1.47 \pm 0.19 \mathrm{y}^{-1}$ of SFS without significant difference between them in spite of their origins, being endemic against exotic and living leaves against fallen leaves. Mass of leaf litter produced by a storm in this area showed $\mu$ values basing on dry matter loss in litter-bags to be $\mu=1.32 \pm 0.23 \mathrm{y}^{-1}$ at a mature rain forest stand (PIN) $600 \mathrm{~m}$ a.s.l. and $\mu=1.48 \pm 0.42 \mathrm{y}^{-1}$ at a stand $630 \mathrm{~m}$ a.s.l. (Yoneda, 1997). The $\mu$ value as the ratio of annual leaf-fall rates to leaf-litter accumulation in $\mathrm{A}_{0}$ layer was $\mu=1.38 \mathrm{y}^{-1}$ at PIN. Differences of altitude considered, slightly higher values of this study would be reasonable, when we could regard $\mu=\mu_{\mathrm{c}}$ due to little contamination of soils for these litter at PIN and a stand at higher elevation. Kira (1978) estimated $\mu_{c}$ values of fine litter in $A_{0}$-layer at a lowland rain forest in Pasoh, Peninsular Malaysia to be $1.70 \mathrm{y}^{-1}$ based on the former model.

Average temperature coefficient $Q_{10}$ of $\mu_{c}$ between MIKASA and HPPB was $Q_{10}=2.19 \pm 0.26$. This value was not largely different with the temperature dependency of decomposition factor $\beta$ of woody litter at humid forest ecosystems in Southeast Asia and Japan, $\mathrm{Q}_{10}=2$ (Yoneda, 1986). 


\section{CONCLUSION}

Our observation by the litter-bag method at an interval of three months could reveal convex seasonal changes of decay ratio on the first-year process at a warm-temperate oak forest in Japan, when decomposition started in winter season. This result suggested that starting time of decomposition was an important parameter for decay rates at sites having clear seasonal changes in climate because of interaction of internal factors and environmental factors. A tropical rain forest in Sumatra had prominent high decay ratio during the first three months, and then tended to be constant under nonseasonal climatic conditions. However, severe dry weather over two months under ENSO largely depressed decay rates as well as prominent decrease of growth rates of many canopy trees in this forest (Yoneda, 2000) simultaneously. We could assess effects of annual mean temperature on average decay ratio to be $\mathrm{Q}_{10}=2.19 \pm 0.26$ between two study forests. Basing on the similar behavior of $C / N$ ratio on the decay processes between both forests, fungi association was considered to be major decomposers in these forests.

ACKNOWLEDGEMENTS This study was carried out under Japan-Indonesian Cooperative Project titled by "Field Biology Research and Training (FBRT)" funded by JICA. We wish to express our thanks to leaders of the project, Syunzo Kawamura, Ryoichi Ohgushi and Amsir Bakar.

\section{REFERENCES}

Dowding, P. 1976. Allocation of resources, nutrient uptake and release by decomposer organisms. In: Anderson, J. M. \& Macfadyen, A. (eds.), The Role of Terrestrial and Aquatic Organisms in Decomposition Processes, 169-183. Blackwell Scientific Publications, Oxford.

Gotz, J. R., Likens, G. E. \& Bormann, F. H. 1973. Nutrient release from decomposing leaf and branch litter in the Hubbard Brook Forest, New Hampshire. Ecological Monograph 47: 173-191.

Kira, T. 1978. Carbon cycling. In: Kira, T., Ono, Y. \& Hosokawa T. (eds.), Biological Production in a Warm-temperate Evergreen Oak Forest of Japan, JIBP Synthesis 18: 272-276. University of Tokyo Press, Tokyo.

Kirita, H. \& Hozumi, K. 1969. Loss of weight of leaf litter caught in litter trays during the period between succesive collections - a proposed correction for litterfall data to account for the loss. Japanese Journal of Ecology 19: 243-246.

Koshimizu, T., Iwata, S., Suganuma, T., Kitagawa, N. \& Hamada, M. 1971. Nature and history of Nara City. In: Koshimizu, T. (ed.), Nature in Nara City, 109-260. Nara Municipal Office, Nara. (in Japanese).

Kuhnelt, W. 1961. Soil Biology - With Special Reference to the Animal Kingdom. 397pp. Faber and Faber, London.

Nakane, K. 1975. Dynamics of soil organic matter in different parts of a slope under evergreen oak forest. Japanese Journal of Ecology 25: 206-216. (in Japanese with English summary)

Nanami, S., Kawaguchi, H. \& Yamakura, T. 1999. Dioecy-induced spatial patterns of two codominant tree species, Podocarpus nagi and Neolitsea acidulata. Journal of Ecology 87: 678-687.

Nishioka, M. \& Kirita, H. 1978. Litterfall. In: Kira, T., Ono, Y. \& Hosokawa T. (eds.), Biological 
Production in a Warm-temperate Evergreen Oak Forest of Japan, JIBP Synthesis 18: 231-238. University of Tokyo Press, Tokyo.

Ogawa, H., Yoda, K. \& Kira, T. 1961. A preliminary survey on the vegetation of Thailand. Nature \& Life in SE Asia 1: 21-157.

Olson, J.S. 1961. Energy storage and the balance of producers and decomposers in ecological systems. Ecology 44: 322-331.

Staaf, H. \& Berg, B. 1982. Accumulation and release of plant nutrients in decomposing Scots pine needle litter. Long-term decomposition in a Scots pine forest II. Canadian Journal of Botany 60:1561-1568.

Swift , M. J., Heal, O. W. \& Anderson, J. M. 1979. Decomposition in terrestrial ecosystems., 372pp. Studies in Ecology Vol. 5. Blackwell Scientific Publications, Oxford.

Witkamp, M. 1966. Decomposition of leaf litter in relation to environment, microflora, and microbial respiration. Ecology 47: 194-201.

Yoda, K. \& Kira, T. 1969. Comparative ecological studies on three main types of forest vegetation in Thailand V. Accumulation and turnover of soil organic matter, with notes on the altitudinal soil sequence on Khao (Mt.) Luang, peninsular Thailand. Nature \& Life in SE Asia 6: 83-110.

Yoneda, T. 1975. Studies on the rate of decay of wood litter on the forest floor. I. Some physical properties of decaying wood. Japanese Journal of Ecology 25: 40-46.

- 1986. Decomposition of wood litter in a forest. Japanese Journal of Ecology 36: 117-129. (in Japanese with English Summary)

- 1997. Decomposition of storm generated litter in a tropical foothill rain forest, West Sumatra, Indonesia. TROPICS 7: 81-92.

- 2000. General and regional properties of decomposition in a forest ecosystem. TROPICS 9: 179-193. (in Japanese with English Summary)

- Nishimura, S. \& Chairul 2000. Impacts of dry and hazy weather in 1997 on a tropical rainforest ecosystem in West Sumatra, Indonesia. Ecological Research 15: 63-71.

Received Oct. 5, 2001

Accepted Oct. 29, 2001

\section{CHAIRUL, 米田 健 照葉樹林と熱帯多雨林での落葉の分解過程に関する比較研究}

日本の照葉樹林とインドネシアの熱帯多雨林における林床での葉部リターの分解に及ぼす外部環境の影響 を, 同じリターを用いたリターバッグ法による 1 年間の観測結果に基づき考察した. 照葉樹林において分解 が冬から始まった場合, その後 1 年間の炭素重量の減少パターンは第 1 近似としてひとつの指数関数曲線 で近似することができ, 材料とした照葉樹林の 5 種類のカシ類の葉部リターの平均分解率は $0.70 \pm 0.13 \mathrm{y}^{-1}$ で あった. しかし，3 ケ月間隔での評価では分解率に季節変化が現れた. 一方, 熱帯多雨林においては, 分解 初期の 3 ケ月間での重量減少がとくに大きかった. また, 観測期間中に発生した 2 ヶ月間に及ぶ異常乾期中 では分解率が大きく低下した. 異常乾期を除く期間から推定した平均分解率は, 照葉樹林のカシ類の葉を 基質とした場合は $1.62 \pm 0.24 \mathrm{y}^{-1}$ で, 両観測地の年平均気温から推定した温度倸数は, 5 種の平均で $\mathrm{Q}_{10}=2.19 \pm$ 0.26 であった. 基質の $C / N$ 比は重量減少とともに減少し, 分解過程の後半では両森林において基質の違いに かかわらず $C / N=20$ で一定となる傾向を示した. これら分解率とその季節変化, さらに $C / N$ 比の変化に基づ き, 両森林生態系の林床での葉部リターの分解過程の特徵を考察した. 